\title{
Implikasi Demokrasi Yang Timbul Dalam Pemilihan Kepala Daerah Secara Langsung Terhadap Kondisi Sosial Politik Masyarakat Daerah
}

\author{
Sarbaini \\ Magister Hukum, Universitas Batanghari Jambi \\ Jl. Slamet Riyadi, Broni, Jambi- Indonesia Tel / Faks: 0741-667084 \\ Correspondence email: sarbaini@unbari.ac.id
}

\begin{abstract}
Abstrak. Sistem Pemilihan Kepala Daerah secara langsung lebih baik dalam mengakomodir kepentingan rakyat dibandingkan dengan sistem Pemilihan Kepala Daerah secara tidak langsung. Pemilihan Kepala Daerah langsung diyakini memiliki kapasitas yang memadai untuk memperluas partisipasi politik masyarakat, sehingga masyarakat daerah memiliki kesempatan untuk memilih secara bebas pemimpin daerahnya tanpa suatu tekanan, atau intimidasi. Sehingga melalui kajian ini menjelaskan dan menganalisis implikasi yang timbul secara positif dan negative terhadap pelaksanaan system pemilihan kepala daerah secara langsung.
\end{abstract}

Kata Kunci : Implikasi, Pemilihan Kepala Daerah Langsung

Abstract. The direct regional head election system is better at accommodating the interests of the people than the indirect regional head election system. Direct regional head elections are believed to have sufficient capacity to expand community political participation, so that local people have the opportunity to freely choose their regional leaders without pressure or intimidation. So that through this study explain and analyze the implications that arise positively and negatively on the implementation of the direct regional head election system.

Keywords : Implications, Direct Regional Head Election

\section{PENDAHULUAN}

Pemilihan Kepala Daerah di Negara Republik Indonesia merupakan momen bersejarah bagi bangsa Indonesia. Bentuk birokrasi yang selama ini hanya dilakukan oleh elit politik dan menutup akses dari partisipasi rakyat, sekarang berubah drastis menjadi tunduk pada kedaulatan rakyat. Pelaksanaan Pemilihan Kepala Daerah berdampak pada peran besar yang diberikan rakyat untuk menentukan kepala daerahnya masing-masing. ${ }^{1}$ Pemilihan kepala daerah secara langsung, merupakan langkah maju proses demokratisasi di Indonesia. Bergulirnya reformasi membuat masyarakat menjadi relatif lebih kritis. ${ }^{2}$ Untuk mengukur tingkat kesadaran politik masyarakat, Proses pelaksanaan Pemilihan Kepala daerah sangat diminati sebagai salah satu barometer partisipasi dan tingkat kesadaran masyarakat akan politik yang memberikan gambaran akan bentuk-bentuk partisipasi masyarakat terhadap politik itu sendiri. Indikasi dari partisipasi politik dengan adanya pilkada berimplikasi kepada keinginan politik masyarakat untuk ikut berkompetisi mengambil posisi strategis politik dalam menentukan pemimpin di daerahnya sehingga mempengaruhi pemikiran dan pandangan yang optimis dalam masyarakat politik yang siap untuk mengikuti kompetisi dalam Pemilihan Kepala Daerah dengan menggunakan hak suaranya dalam menentukan Kepala Daerah Secara yuridis Pemilihan Kepala Daerah secara langsung diatur dalam Undang-Undang No. 32 tahun 2004 sebagai revisi dari Undang-Undang No. 22 Tahun 1999 yang memuat regulasi Pemilihan Kepala Daerah secara langsung. Seperti juga telah tertuang dalam Pasal 18 ayat (4) UUD 1945, bahwa Gubernur, Bupati Dan Walikota, masing-masing sebagai kepala pemerintahan daerah provinsi, kabupaten dan kota dipilih secara demokratis.

Pemilihan Kepala Daerah langsung menjadikan rakyat dengan pemerintah semakin dekat dan tanggung jawab kepala daerah yang dipilih secara langsung benar-benar tertuju kepada rakyat. Tujuan utama Pemilihan Kepala Daerah langsung adalah penguatan masyarakat dalam rangka peningkatan kapasitas demokrasi di tingkat lokal dan peningkatan harga diri masyarakat yang sudah sekian lama dimarginalkan di daerah. ${ }^{3}$ Bahwa sistem Pemilihan Kepala Daerah secara langsung lebih baik dalam mengakomodir kepentingan rakyat dibandingkan dengan sistem Pemilihan Kepala Daerah secara tidak langsung. Pemilihan Kepala Daerah langsung diyakini memiliki kapasitas yang memadai untuk memperluas partisipasi politik masyarakat, sehingga masyarakat daerah memiliki kesempatan untuk memilih secara bebas pemimpin daerahnya tanpa suatu tekanan, atau intimidasi, floating mass atau massa mengambang, kekerasan politik, maupun penekanan jalur birokrasi. Dapat dikatakan pilkada merupakan momentum yang cukup tepat munculnya berbagai varian referensi pemilih yang menjadi faktor dominan dalam melakukan tindakan atau

\footnotetext{
${ }^{1}$ Anonim, Pemilihan Kepala Daerah Langsung: Berebut Kursi Panas dalam Tempo, Edisi 9-15 januari 2006, hal. 199
}

${ }^{2}$ Ibid, hal. 201

${ }^{3}$ Saukani HR, Affan Gaffar, dan Ryass Rasyid, Otonomi Daerah dalam Negara Kesatuan, Pustaka Pelajar, Yogyakarta, 2002, hal. 21 
perilaku politiknya. ${ }^{4}$ Studi yang dilakukan oleh Mujani \& Liddle ${ }^{5}$ menghasilkan beberapa temuan penting mengenai rasionalitas pemilih serta figur kandidat dan partai politik. Pemilih telah menetapkan standar tujuan atau prioritas keberhasilan pemimpin berupa: pertumbuhan ekonomi, kemakmuran, persatuan nasional, pendidikan, dan penegakan hukum. Masyarakat lebih percaya pada individu-individu ketimbang partai politik, dengan standar individu berupa integritas pribadi, kepedulian sosial, dan kompetensi profesional.

Terjadinya perubahan yang signifikan dalam politik di negara Indonesia sebagai wujud memperkuat pemerintah rakyat turut berpartisipasi sehingga partai politik cenderung untuk mencalonkan orang yang populer. Periode sebelumnya orang lebih memfokuskan pada pengaruh politik atau kapasitas finansial seseorang, namun popularitas telah menggeser hal tersebut. Popularitas dan kemampuan finansial individu selama ini menjadi senjata yang paling diminati oleh partai politik selama menentukan calon Kepala Daerah yang akan dipilih dalam pemilu. ${ }^{6}$

\section{PEMBAHASAN}

\section{A. Implikasi Positif Pemilihan Kepala Daerah Secara Langsung}

a. Rakyat dapat mengetahui langsung dan dapat mengontrol jalannya pemerintahan;

b. Rakyat terlibat langsung dalam menentukan Kepala Daerah;

c. Rakyat bebas menentukan Kepala Daerah dan Wakil Kepala Daerah.

\section{B. Implikasi Negatif Pemilihan Kepala Daerah Secara Langsung}

\section{a. Pasangan Calon Mengeluarkan Biaya Yang Besar}

Dari prakteknya pemilihan kepala daerah secara langsung seharusnya semakin membaik kedepannya dalam pertumbuhan demokrasi di Indonesia, karena dalam perjalanannya pemilihan kepala daerah secara langsung yang telah dijalankan puluhan tahun sehingga terlihat kelemahan dan kelebihannya terutama terhadap pasangan calon yang diajukan oleh partai politik maupun gabungan partai politik serta calon perseorangan, dimana dalam mengajukan pasangan calon partai politik maupun gabungan partai politik hanya semata-mata melihat pasangan calon tersebut dari kemampuan finansial dan ketokohannya, akan tetapi tidak memperhatikan kapabilitasnya sebagai calon pemimpin, sehingga yang selama ini kepala daerah yang terpilih tidak seluruhnya memenuhi keinginan rakyat pendukungnya, terbukti banyaknya kepala daerah yang semasa pencalonan dirinya mengeluarkan biaya yang besar: untuk menjadi calon yang akan diusung oleh partai politik maupun gabungan partai politik, karena untuk menjadi pasangan calon Kepala daerah terlebih dahulu partai politik meminta kepada pasangan calon untuk mendapatkan dukungan dari partai politik dan gabungan partai politik, sebaiknya sebelum pencalonan calon untuk menjadi kepala daerah yang selama ini menurut Undang-Undang Nomor 32 Tahun 2004 bahwa baik calon Kepala daerah maupun calon wakil Kepala daerah, keduanya sama-sama melakukan Lobi politik kepada partai yang akan mengusungnya, dimana calon kepala daerah dan calon wakil kepala daerah tersebut jika dianggap sebagai pasangan yang memiliki persamaan visi dan masa maka masing-masing partai poitik yang mendukung bergabung untuk mendukung pasangan calon kepala daerah tersebut, hanya saja tinggal menentukan oleh partai politik gabungan siapa yang menjadi kepala daerah dan siapa pula yang menjadi wakil kepala daerah. Dukungan tersebut bukan hanya sekedar dukungan, namun dukungan tersebut ditentukan oleh besar mahar yang disanggupi oleh masing-masing calon tersebut, hal itu adalah merupakan sisi negatif didalam pemilihan kepala daerah secara langsung karrena disamping membayar mahar yang besar, jika kepala daerah tersebut terpilih maka masing-masing pendukung maupun calon yang bersangkutan bersikap tidak saling mendukung dalam menjalankan roda pemerintahan di daerah bahkan banhyak sekali wakil kepala daerah beserta partai pendukungnya berharap agar kepala daerahnya tersandung kasus dengan harapan, jika kepala daerah tersandung kasus maka wakil kepala daerahnya akan menjadi kepala daerah sebagai pengganti kepala daerah yang sedang menjalankan proses hukum. Sikap yang demikian juga termasuk bertentangan dengan asas Jujur dan Adil. Oleh karena itu kedepannyauntuk memilih wakil kepala daerah apakah wakil gubernur/walikota/bupati sebaiknya dipilih oleh calon gubernur, walikota/bupati di daerahnya. Dengan demikian pasangan calon tersebut akan sejalan dan sinergi dengan masyarakatnya dalam menjalankan roda pemerintahannya yang berimplikasi kemajuan bagi daerahnya maupun perekonomian masyarakatnya.

Implikasi negatif atas pemilihan kepala daerah secara Langsung berdasarkan data empiris yaitu berupa:

1. membayar uang mahar politik yang mahal kepada partai maupun gabungan partai politik,

2. menggunakan biaya untuk mobilisasi massa yang besar,

3. membeli suara rakyat (money politics),

4. lamanya masa sosialisasi yang menyedot biaya yang besar,

${ }^{4}$ Firmanzah, Pemilihan Umum dan Pemilihan Kepala Daerah Dalam Era Reformasi, 2007, hal. 34

${ }^{5}$ Mujani \& Liddle dalam Syamsudin Haris, Litera Antar Nusa, Jakarta, 2010, hal. 27

${ }^{6}$ Mietzner dalam Titik Triwulan Tutik, Pemilihan Kepala Daerah Berdasarkan Undang-Undang Nomor32 Tahun 2004 dalam System Pemilu menurut UUD 1945. Jakarta: Prestasi Pustaka, 2006, hal. 121 
Sehingga pasangan calon yang terpilih dengan menggunakan biaya yang besar tidak fokus memperhatikan kesejahteraan rakyatnya dan kemajuan daerahnya, akan tetapi justru berusaha bagaimana cara mengembalikan biaya yang besar yang telah dikeluarkan selama pencalonan dirinya, apalagi calon kepala daerah tersebut ingin mencalonkan untuk periode selanjutnya. Sehingga kesempatan dan kewenangan yang ada pada dirinya digunakan untuk mengumpulkan uang sebagai pengganti dan modal untuk pencalonan periode selanjutnya. Maka tidak sedikit kepala daerah yang tersandung kasus korupsi. Bayangkan saja, dari tahun 2004 sampai tahun 2018 jumlah kepala daerah yang tersandung korupsi selalu mengalami peningkatan yang cukup signifikan. Total Kepala daerah yang tersandung kasus korupsi adalah 121 orang, dimana terdapat 20 Gubernur dan untuk Bupati/Walikota terdapat 101 orang yang tersandung kasus Korupsi, dari Tahun 2016 sampai tahun 2018 Kepala daerah yang tersandung kasus korupsi mengalami peningkatan hingga $43 \%$

menunjukkan bahwa pemilihan kepala daerah secara langsung memiliki implikasi negatif, sehingga untuk kedepannya bahwa pasangan calon yang akan diusung oleh partai politik tidak semata-mata dipilih oleh partai politik, akan tetapi untuk wakil kepala daerah harus dipilih dan ditentukan oleh calon kepala daerah sehingga partai politik hanya menerima pasangan calon yang untuk diusung, dimana terlebih dahulu telah dapat ditentukan oleh masyarakat. Dengan cara sistem demikian, maka partai politik tidak dapat berbuat sewenang-wenang untuk menentukan mahar politik kepada pasangan calon yang akan diusungnya jika perlu ditentukan di dalam aturan tentang tata cara mengusung pasangan calon kepala daerah untuk memperebutkan suara rakyat menjadi pemimpin di daerahnya, sehingga dengan demikian pasangan calon yang akan mencalon tidak mengeluarkan biaya yang besar jika pasangan calon tersebut terpilih maka sebagai Kepala Daerah akan fokus untuk membangun daerahnya, memajukan perekonomian daerah, mensejahterakan masyarakat yang dipimpinya karena tidak akan memikirkan cara untuk mengembalikan uangnya yang telah habis semasa pencalonan dirinya.

Menurut hasil survei, masyarakat dalam menentukan pemimpin di daerahnya menginginkan dan menentukan sendiri sesuai dengan keinginannya daripada pemimpin yang ditentukan oleh partai politik, hal itu terjadi karena masyarakat telah memilih pengetahuan politik yang semakin tinggi. ${ }^{7}$ Kriteria Pemimpin yang dapat mempengaruhi masyarakat dalam menentukan figur yang akan dipilihnya lebih cenderung kepada kepribadian pemimpin ketimbang pengalaman dalam pemerintahan, kinerja masa lalu, dan platform (visi-misi) calon, apalagi diakhir-akhir ini banyaknya Kepala Daerah yang tersandung Korupsi maka calon yang korup tidak diinginkan oleh masyarakat apalagi calon tersebut adalah incumbent. Masyarakat menilai calon incumbent cenderung akan korupsi karena ingin mengembalikan uang yang dikeluarkan semasa pencalonan dirinya atau dengan kata lain ingin mengembalikan modal politik yang besar yang telah dikeluarkannya. Oleh Karena itu dalam iklim politik di Indonesia sekarang ini yang penuh dengan persaingan terbuka dan transparan, pasangan calon yang akan ikut sebagai kontestan Pemilihan Umum Kepala Daerah membutuhkan suatu metode yang dapat memfasilitasi Pasangan Calon dalam menjual isu politik, gagasan politik, inisiatif politik, serta ideologi partai politik..Agar suatu Pasangan Calon Kepala Daerah dapat memenangkan pemilihan umum, ia harus dapat membuat pemilih berpihak dan memberikan suaranya. Hal ini hanya akan dapat dicapai apabila kontestan memperoleh dukungan yang luas dari pemilih. ${ }^{8}$

\section{b. Faktor Partisipasi Masyarakat Berimplikasi Negatif}

Masyarakat yang telah mempunyai hak sebagai Pemilih adalah subyek partisipasi, sehingga masyarakat tersebut sebagai pemilih memiliki kemandirian yang bebas dalam membangun kesadaran Politik dan merumuskan pilihannaya serta, mengekspresikan pilihannya. Dalam bahasa yang lain para pemilih merupakan rational voters yang mempunyai tanggung jawab, kesadaran, kalkulasi, rasionalitas dan kemampuan kontrol yang kritis terhadap kandidat pilihannya, yang akhirnya masyarakat pemilih meninggalkan ciri-ciri traditional voters yang fanatik, primordial, dan irasional, lain lagi swingers voters yangmana pemilih masih ragu-ragu dan cenderung berpindah-pindah pilihan politiknya. ${ }^{9}$ Ada tiga faktor yang mempengaruhi pemilih dalam menentukan pilihannya terhadap pasangan calon kepala daerah, yaitu:

1. Dukungan dari partai politik yang mapan dan solid pendukungnya maka pasangan calon memperoleh dukungan yang besar dan begitu pula sebaliknya.

2. Program yang dijual oleh partai politik tentang kemapanan dan keberhasilan partainya dalam mengusung pasangan calon yang telah diusungnya. Sedangkan untuk partai yang baru dilihat dari isu menarik yang dapat menyentuh langsung kepada rakyat dan partia tersebut dianggap masih "bersih".

3. penampilan kandidat, dimana performa kandidat sangat menentukan keberhasilan kandidat. ${ }^{10}$

${ }^{7}$ S.V. Sharma, Ideologi-ideologi Politik Kontemporer, Alumni, ${ }^{7}$ Mietzner dalam Titik Triwulan Tutik, Pemilihan Kepala Daerah Berdasarkan Undang-Undang Nomor 32 Tahun 2004 dalam System Pemilu menurut UUD 1945. Jakarta: Prestasi Pustaka, 2006, hal. 121

${ }^{7}$ S.V. Sharma, Ideologi Politik, Alumni, Bandung, 2010, hal. 14

${ }^{8}$ Firmanzah, Op.Cit., hal. 21

${ }^{9}$ Riyanto, Ilmu Politik Mashab Machiavelli, Libety, Yogyakarta, 2004, hal. 154

${ }^{10}$ Malian dalam Kushartono, Teori-teori Politik Kontemporer, Djambatan, Jakarta, 2006, hal. 31 
Keberhasilan pemerintah sebelumnya dalam membangun daerahnya menjadi perhatian utama bagi masyarakat terhadap kinerja calon yang telah pernah memerintah atau dengan kata lain calon incumbent, jika keberhasilannya itu dinilai oleh masyarakat adalah berhasil, maka calon kepala daerah yang ikut kontestan politik berikutnya akan mendapatkan dukungan yang besar, namun sebaliknya jika tidak ada keberhasilan dalam pemerintahan sebelumnya maka pasangan calon tersebut tidak akan dapat dukungan yang besar atau ditinggalkan oleh pendukungnya dalam pemilihan selanjutnya. Oleh karena itu wacana praktik demokrasi saat ini, harus diakui bahwa penyelenggaran pemilu Kepala Daerah secara langsung merupakan awal upaya penyelenggaraan pemerintahan yang demokratis dalam sistem pemerintahan daerah yang semula sentralistis menjadi desentralistis. Implikasinya, terjadi pergeseran lokus kekuasan, dari pusat ke daerah. Pemilihan secara langsung kepala daerah dalam hal ini bupati dan walikota, melahirkan penafsiran-penafsiran negatif, terutama sikap partai politik yang berkuasa selalu melakukan penekanan terhadap birokrasi/pegawai Negeri Sipil (PNS). Birokrasi selalu diserahkan karena politik praktis dalam pelaksanaan pemilukada.

Sejalan dengan itu Miftah Thoha mengemukakan bahwa; "Bagi partai politik yang memenangkan suara dalam pemilihan umum, maka partai politik dalam suatu sistem negara demokrasi bisa memimpin dan mengendalikan pemerintahan. Kehadiran partai politik dalam pemerintahan akan menjadi master dari birokrasi pemerintah. ${ }^{11}$ Dalam perkembangannya pengorganisasian birokrasi sangat diwarnai dengan ketidakpastian akibat peran Kepala daerah sebagai pembina kepegawaian di daerah dan peran partai politik yang saling bersaing dengan sangat dominan, Bupati/wali Kota dan partai-partai politik yang berkuasa seenaknya melakukan building block kekuasaan melalui dinas-dinas birokrasi yang strategis di jajaran pemerintahan sebagai sumber daya kelangsungan partai politik yang bersangkutan, program rekrutmen birokrasi ikut mengalami spoil sistem yang merajalela mulai dari pengangkatan, penempatan, promosi dan instrumen kepegawaian lainnya tidak didasarkan kriteria penilaian melainkan berdasarkan pertimbangan politik, golongan serta unsur-unsur lainnya di luar tugas birokrasi. Dengan demikian pemilihan umum kepala daerah secara langsung sejatinya ditujukan untuk memperdalam demokrasi di Indonesia. Namun selama ini pengalaman pemilukada langsung justru menimbulkan dampak negatif dalam kehidupan birokrasi khususnya di daerah. Sesuai dengan UU No. 5 th 2014 tentang ASN yang menyatakan "ASN adalah pegawai pemerintah yang memiliki integritas, profesional, netral dan bebas dari intervensi politik, serta bebas dari KKN, semestinya harus bersikap netral dan tidak memihak kesalah satu partai atau calon kepala daerah. Selanjutnya Miftah Thoha mengungkapkan bahwa; "Birokrasi itu bekerja sesuai dengan profesionalisme yang dituntut kepadanya sepanjang masa, dan tidak boleh terkontaminasi oleh warna politik yang datang silih berganti memimpinnya. ${ }^{12}$ Untuk menjamin adanya kepastian hukum, atas sikap netralitas birokrasi/Pegawai Negeri Sipil telah ditegaskan dalam Undang-undang Nomor 43 Tahun 1999 tentang pokok-pokok kepegawaian.

Pada saat dimulainya reformasi maka melalui Peraturan Pemerintah Nomor 5 Tahun 1999 mengenai keberadaan pegawai negeri sipil (PNS) sebagai anggota partai politik lalu diubah melalui Peraturan Pemerintah Nomor 12 Tahun 1999 yang membuat pegawai negeri sipil (PNS) kembali tertutup dari kemungkinan untuk ikut berkiprah sebagai keanggotaan dalam partai politik apapun. Selanjutnya Deden Mariana Carolina Paskarina mengemukakan bahwa "pada prakteknya, sistem pemilihan kepala daerah langsung ini memang tidak secara otomatis membawa perubahan yang lebih baik dalam tata kelola pemerintahan daerah. ${ }^{13}$ Peluang money politics, manipulasi, politisasi adat dan ikatan primordial, serta mobilisasi massa tetap berlangsung. Para elit politik tetap berperan dominan dalam pilkada, minimal dalam menentukan pasangan calon yang akan berlaga dalam pilkada. Masyarakat hanya berperan dalam memberikan suara bagi para calon yang telah ditentukan para elit. Meskipun demikian, perlawanan masyarakat terhadap dominasi elit tetap ada. Tingginya persentase golput disejumlah daerah mengindikasikan sikap apatisme masyarakat.

Pemilihan umum kepala daerah merupakan suatu pesta rakyat yang diselenggarakan untuk memilih calon pemimpin, baik dalam ranah kabupaten maupun kota. Sesuai dengan asas pemilu yang Jujur, adil, langsung, umum, bebas, dan rahasia, maka diharapkan pelaksanaan Pemilu itu sendiri dapat berjalan secara netral dan tidak bersifat diskriminatif. Dengan adanya Badan Pengawas Pemilu (Bawaslu) dari KPU yang mengawasi jalannya pelaksanaan pemilu dapat dikatakan pelaksanaan Pemilu sudah profesional dan netral. Tetapi, pada faktanya di lapangan, tidak semua pelaksanaan Pemilihan Umum calon pemimpin di suatu daerah bebas dari praktek-praktek kotor. Pemilihan Umum yang berlangsung diharapkan oleh sebagian besar masyarakat justru dinodai dengan praktek-praktek

\footnotetext{
${ }^{11}$ Miftah Thoha dalam Bodhi Wedyanto FN dan Seprini (penyunting), Pilkada dan Demokrasi Arus Bawah: Dokumentasi Politik Terpilihnya Zul AS-Sunaryo pada Pilkada Kota Dumai 2005-2010. Pekanbaru: ISDP, 2006. Hal. 33

${ }^{12}$ Muryanto Amin, Sistem Pemilihan Kepala Daerah Langsung: Beberapa Masalah, Implikasi Politik dan Solusinyall, dalam Politeia: Jurnal Ilmu Politik. Vol.I, Nomor 1 Juni 2005, hal. 329

${ }^{13}$ Deden Mariana Carolina Paskarina, Pemilihan Kepala Daerah, Litera Antar Nusa, Jakarta, 2014, hal. 71
} 
kecurangan dari pihak tim sukses maupun kecurangan dalam penghitungan suara. ${ }^{14}$ Hal ini merupakan suatu gambaran yang pilu bagi Pemilihan Umum di Indonesia, karena Pemilihan Umum yang diusung dengan asas keadilan dan netralitas ternyata dalam menyukseskannya harus dibayar dengan kecurangan. Berbagai macam bentuk kecurangan yang terjadi dalam Pemilihan Umum di daerah. Salah satunya adanya keterlibatan oknum PNS dalam menyukseskan Pemilukada.

Mengacu pada UU RI No 43 tahun 1999 tentang perubahan atas UU RI No 8 tahun 1974 tentang Pokok-Pokok Kepegawaian Pasal 3 ayat (1) menjelaskan bahwa PNS berkedudukan sebagai unsur aparatur negara yang bertugas untuk memberikan pelayanan kepada masyarakat secara profesional, jujur, adil, dan merata dalam penyelenggaraan tugas negara, pemerintahan, dan pembangunan. Pasal 3 ayat (2) dalam kedudukan dan tugas sebagaimana dimaksud dengan ayat (1), PNS harus netral dari pengaruh semua golongan dan parpol, serta tindak diskriminatif dalam memberikan pelayanan kepada masyarakat. Sedangkan pada Pasal 3 ayat (3) untuk menjamin netralitas PNS sebagaimana dimaksud dalam ayat (2), PNS dilarang menjadi anggota dan/atau pengurus parpol.

Semasa berlakunya UU No. 32 Tahun 2004 tentang Pemerintahan Daerah, bahwa birokrasi atau PNS dibolehkan mencalonkan pilkada, hal ini didukung oleh peraturan tersebut di atas yang diberikan kesempatan oleh parpol atau gabungan parpol, jika dikaitkan dengan netralitas birokrasi dalam pilkada, terbukti birokrasi yang mencalonkan diri sebagai calon kepala daerah atau wakil kepala daerah berarti tidak netral, karena harus melalui parpol dan gabungan parpol (Pasal 59 ayat 1), dan juga diberikan kesempatan tetap berstatus sebagai PNS, karena hanya mengundurkan diri dari jabatan negeri yakni jabatan struktural dan jabatan fungsional (Pasal 59 ayat 5 (g)), oleh karena itu, secara individu dijamin hak asasi manusianya. PNS atau birokrasi yang mencalonkan diri dalam pilkada, terbukti melanggar UU RI No 43 tahun 1999 Pasal 3 ayat 1, 2, dan 3 karena tidak profesional mengingat jabatan pilkada adalah jabatan politik, sedangkan jabatan PNS adalah jabatan karir administratif sebagai pelayan masyarakat yang harus netral, sedangkan jabatan pilkada terkait dengan parpol atau gabungan parpol, dengan demikian melanggar pasal 3 ayat 2 dan ayat 3, sehingga secara institusional birokrasi atau PNS dibatasi hak politiknya. Hal ini dapat dilihat dari penjelasan mengenai keterlibatan birokrasi/PNS dalam keikutsertaan dalam Pemilihan Umum. Dengan adanya keberpihakan suatu oknum pemerintahan dalam penyelenggaraan pemilihan kepala daerah merupakan suatu bentuk dari ketidakadilan dalam Pemilu, di mana masih adanya para oknum pemerintahan yang menggunakan kekuasaannya sebagai "roda penggerak" dalam menyukseskan suatu kelompok dalam kancah perpolitikan. Dijelaskan dalam Undang-Undang Kepegawaian bahwa Pegawai Negeri Sipil (PNS) tidak boleh berpihak kepada satu pihak dan harus bersikap netral dalam menjalankan tugas dan juga dilarang menjadi anggota dan / atau pengurus parpol. ${ }^{15}$

Di samping permasalahan di atas, adanya suatu pelanggaran lainnya yang melibatkan oknum pemerintahan, seperti adanya petugas penyelenggara tingkat desa, kecamatan, kabupaten tidak bertindak netral dalam menjalankan tugas penyelenggaraan pemilukada dan adanya penggunaan dana APBD untuk menjalankan kampanye. Pada permasalahan di atas, dapat dijelaskan bahwa masih tidak berlakunya asas keadilan dalam pemilihan umum yang diselenggarakan, dengan adanya keikutsertaan dari oknum-oknum pemerintahan, maka pelaksanaan dari pemilihan umum bersifat lebih mengedepankan kepentingan kelompok dibandingkan kepentingan umum, karena banyak dari oknum pemerintahan yang menyalahgunakan wewenang dalam menjalankan tugasnya untuk mendukung salah satu calon kandidat dalam Pemilukada. Kalau dilihat dari berbagai sisi bahwa semua stakeholder ingin mengupayakan pentingnya untuk melihat proses Pilkada sebagai bagian integral dari proses demokratisasi di Indonesia, dengan mengupayakan semua penyelenggaraan pemilu yang berdasarkan asas-asas pemilu yang berdasarkan UU No. 7 Tahun 2017 yang terdiri dari mandiri, jujur, adil, kepastian hukum, tertib, kepentingan umum, keterbukaan, proporsionalitas, profesionalitas, akuntabilitas, efisiensi dan efektifitas, namun ketika melihat berbagai permasalahan di daerah tentang netralitas birokrasi PNS yang cenderung menjadi" roda politik". Bagaimana birokrasi yang seharusnya melayani masyarakat malah terjun dalam ranah politik yang cenderung tidak netral, sehingga dirasa perlu untuk mengembalikan citra birokrasi yang harus netral secara politik, namun upaya tersebut dirasakan sangat tidak mudah karena banyak berbagai faktor yang menjadi kendala di dalam mengupayakan birokrasi yang netral secara politik dan melayani masyarakat secara lebih adil dan berasaskan kepentingan umum.

\section{KESIMPULAN}

Pemilihan kepala daerah secara langsung, merupakan langkah maju proses demokratisasi di Indonesia. Bergulirnya reformasi membuat masyarakat menjadi relatif lebih kritis. ${ }^{16}$ Untuk mengukur tingkat kesadaran politik masyarakat, Proses pelaksanaan Pemilihan Kepala daerah sangat diminati sebagai salah satu barometer partisipasi dan tingkat kesadaran masyarakat akan politik yang memberikan gambaran akan bentuk-bentuk partisipasi masyarakat terhadap

\footnotetext{
${ }^{14}$ Cecep Effendi, Evaluasi Kritis Pelaksanaan Pemilihan Kepala Daerah Secara Langsung\| dalam Politeia: Jurnal Ilmu Politik. Vol.I, Nomor 1 Juni 2005, hal. 399

${ }^{15}$ Laode Ida, Pemilihan Langsung Kepala Daerahdalam JURNAL PSPK. Edisi 5, Jakata, 2003, hal. 219

${ }^{16}$ Ibid, hal. 201
} 
politik itu sendiri. Dalam pelaksanaannya membawa dampak positif dan negative dalam penyelenggaraan. Dampk negative hal ini dipengaruhi oleh berbagai factor-faktor kendala didalam mengupayakan pelaksaan pemilihan kepada daerah secara langsung sehingga dihasilkan pemilihan yang netral secara politik dan memberikan kepuasan kepada masyarakat secara adil berasaskan kepentingan umum

\section{DAFTAR PUSTAKA}

\section{BUKU :}

Anonim, Pemilihan Kepala Daerah Langsung: Berebut Kursi Panas dalam Tempo, Edisi 9-15 januari 2006

Firmanzah, Pemilihan Umum dan Pemilihan Kepala Daerah Dalam Era Reformasi, 2007

Mujani \& Liddle dalam Syamsudin Haris, Litera Antar Nusa, Jakarta, 2010

Mietzner dalam Titik Triwulan Tutik, Pemilihan Kepala Daerah Berdasarkan Undang-Undang Nomor32 Tahun 2004 dalam System Pemilu menurut UUD 1945. Jakarta: Prestasi Pustaka, 2006

S.V. Sharma, Ideologi-ideologi Politik Kontemporer, Alumni, ${ }^{1}$ Mietzner dalam Titik Triwulan Tutik, Pemilihan Kepala Daerah Berdasarkan Undang-Undang Nomor 32 Tahun 2004 dalam System Pemilu menurut UUD 1945. Jakarta: Prestasi Pustaka

S.V. Sharma, Ideologi Politik, Alumni, Bandung, 2010, hal. 14

Riyanto, Ilmu Politik Mashab Machiavelli, Libety, Yogyakarta, 2004

Malian dalam Kushartono, Teori-teori Politik Kontemporer, Djambatan, Jakarta, 2006,

Miftah Thoha dalam Bodhi Wedyanto FN dan Seprini (penyunting), Pilkada dan Demokrasi Arus Bawah: Dokumentasi Politik Terpilihnya Zul AS-Sunaryo pada Pilkada Kota Dumai 2005-2010. Pekanbaru: ISDP, 2006

\section{JURNAL :}

Muryanto Amin, Sistem Pemilihan Kepala Daerah Langsung: Beberapa Masalah, Implikasi Politik dan Solusinyall, dalam Politeia: Jurnal Ilmu Politik. Vol.I, Nomor 1 Juni 2005,

Laode Ida, Pemilihan Langsung Kepala Daerahdalam JURNAL PSPK. Edisi 5, Jakata, 2003, 